\title{
EFFORTS TO INCREASE THE TEACHER'S GROUP TEACHER COMPETENCY THROUGH THE TEACHER WORK GROUPS IN CENTRAL BAKUNG CIMAHI
}

\author{
Syah Khalif Alam \\ IKIP Siliwangi \\ radityaalief@gmail.com
}

\begin{abstract}
This study aims to determine the implementation process and the results of teacher competency development in the group of teachers of the kindergarten cluster Bakung Cimahi Tengah. The formulation of the problem in this research is whether the teacher working group can improve the competence of kindergarten teacher group in Central Cimahi? And how the implementation process, the results of coaching, advantages, and disadvantages after the guidance of pedagogic competence of teachers in the cluster group of teachers Cilahi Tengah. The approach used in this research is qualitative approach with descriptive research method. The population in this research is in Cimahi Tengah lily group consisting of 29 teachers from 7 kindergarten schools. Based on the results of research that during the process of implementation of the working group of teachers still do not understand its role as a subject of learning. While the result of guidance pedagogic competence of teachers successfully implemented, the teacher showed an active, enthusiastic, and happy attitude during the learning took place. It can be concluded that improving the competence of teachers through teacher workgroups can experience a significant increase as when supervisors provide direction and guidance look more active and confident, and improve the competence of teachers through teacher work groups more effectively and better, teachers are more understanding and can doing activities well.
\end{abstract}

Keywords: Teacher Competence, Early Childhood Education, Teacher Working Group

\section{A. INTRODUCTION}

Currently, awareness and commitment to early childhood both nationally and internationally are increasing. One of the drivers of awareness and commitment to early childhood is the findings of research on the impact of early childhood education on improving human resources and other areas of life. UNESCO (2011: 38) states that PAUD contributes to (1) increased educational efficiency, ie decreasing repetition rates and improving children's ability to complete higher education, (2) increasing work productivity and welfare, and (3) ) declining crime rates and people with social welfare problems. Various legislation has been issued as a manifestation of commitment to foster early childhood as a whole. These commitments, among others, are contained in Law no. 20 of 2003 on National Education System, Chapter I, article 1, point 14, which states that: Early childhood education (PAUD) is a coaching effort aimed at children from birth up to the age of six years conducted through the provision of educational stimuli to help growth and physical and spiritual development so that children have readiness in entering further education. PAUD is not a field that can be considered light because PAUD requires a unique handling compared with other educators. This is 
due to the developmental characteristics and ways of learning in early childhood are different from children who are older age, so that required a typical guidance also for children to develop optimally. In relation to this, the study of PAUD teachers needs to receive genuine attention (Setiasih, 2009, p.1).

One of the resources/components that must be managed in kindergarten education is the teacher. Teachers get great attention because teachers are a potential resource that plays a role in realizing the goals of national education. Teachers are the spearhead of various efforts to improve the quality of national education because teachers are parties directly involved in the process of learning in the classroom and has a very vital role in improving the quality of their students. Qualifications and competencies of kindergarten teachers are based on Article 26 of Government Regulation Number 19 the Year 2005 on National Education Standards and Regulation of the Minister of National Education of the Republic of Indonesia Number 16 the Year 2007 regarding Academic Qualification Standards and Teacher Competencies. Based on the regulation, kindergarten teacher must have a minimum academic qualification of diploma four (D-IV) or bachelor degree (S1) in 3 Iis Faridah, 2013. The contribution of Teacher Work Competence and Leadership Leadership Instruction Leadership on Teaching Performance of Kindergarten Teacher in town, the field of early childhood education or psychology gained from an accredited course of study.

According to Morrison (Yufiarti and Chandrawati, 2011, p.16) states one of the benchmarks of kindergarten teachers as professional educators is the competence of teachers in teaching. Implementation of the learning process requires optimal teacher competence because the role of teachers is very important for the success of the learning process in the classroom. Teachers play a variety of roles in learning situations, whether as educators, facilitators, mediators, instructors or moderators. The child will provide good cooperation if the teacher shows the seriousness, ethics of teaching and make initiatives to improve the ability of children with patience and high commitment. However, what the child learns, will depend on the teacher's own teaching competence (Enueme and Egwunyenga, 2008, p.1). Teacher teaching competence is the performance of teachers in carrying out their duties and responsibilities to provide guidance learning in the form of knowledge skills that will lead to improved student achievement. Teacher teaching competencies include designing/planning activities, creating learning environments, implementing learning and assessing and communicating learning outcomes (Kentucky Education Professional Standards Boards, 2003, pp. 1-4). Meanwhile, Majid (2011, pp. 91), states that if the teaching and learning process is viewed in terms of teacher activities, then the teacher is seen to play a prime role. It functions as a decision maker related to planning, implementation, and assessment/evaluation. Danim (2002, p 123) states that one of the characteristics of the education crisis in Indonesia is that teachers have not been able to demonstrate adequate competence.

Furthermore, according to Spencer and Spencer in Palan (2007) competence is a basic characteristic possessed by an individual who deals causally in fulfilling the necessary criteria for occupying a position. Competence consists of 5 types of 
characteristics, ie motives (consistent willingness as well as the cause of action), innate factors (character and consistent response), self-concept (selfimage), knowledge (information in a particular field) and skills (ability to perform the task ). This is in line with Becker and Ulrich's opinion (in Suparno, 2005, p.24) that competency refers to an individual's knowledge, skill, ability, or personality, that affects job performance. That is, competence contains aspects of knowledge, skills (skills) and ability or personality characteristics that affect performance. Competence derived from the word "competency" is a noun which according to Powell (1997, p. 142) is defined as 1) competence, ability, competence 2) authority. The adjective of competence is competent which means capable, capable, and agile. According to Spencer and Spencer (in Palan, 2007, pp. 84) suggests that competence exhibits the underlying characteristics of behaviors that describe the motives, personal characteristics, self-concepts, values, knowledge or skills that a superior person performs ( superior performers) at work. There are 5 (five) characteristics that form the competence that is 1). Knowledge factors include technical, administrative, humanitarian, and systemic problems. 2). Skills; refers to a person's ability to perform an activity. 3). Self-concept and values; refers to one's attitudes, values, and self-image, such as one's belief that he can succeed in a situation. 4). Personal characteristics; refers to the physical characteristics and consistency of responses to situations or information, such as self-control and the ability to remain calm under pressure. 5). Motives; our emotions, desires, psychological needs or other drives that trigger action. Based on the above statement implies that competence is a characteristic of a person related to effective performance and or superior in certain job situations. Competence is said to be an underlying characteristic because individual characteristics are an in-depth and inherent part of a person's personality that can be used to predict certain job situations. Then it is said to be related to behavior and performance because competence causes or can predict behavior and performance. From the description of the above understanding can be concluded that the competence is the nature of the possessed or part of a deep personality and attached to a person and the behavior that can be predicted on various circumstances and job tasks as an impetus to have the achievement and the desire to work effectively to perform the task. Incompatibility in these competencies distinguishes a superior offender from a limited performer. Limited competence and special competence for a particular job are patterns or guidelines in personnel selection, succession planning, performance appraisal, and development.

Competence can be interpreted as knowledge, skills, and abilities controlled by someone who has become a part of himself so he can perform cognitive, effective and psychomotor behavior with the best. From the above understanding, it should be noted that many experts define it in different ways but still in one context. In this case, the more emphasized competence in research is pedagogic competence. According to Prof. Dr. J. Hoogveld (Netherlands), pedagogic is a science that studies the problem of guiding the child toward a certain goal, that is, in the future he is "able to independently complete his life tasks". Furthermore, Suwarno suggests that pedagogic means education, which is more emphasis on 
practice, involving educational activities, guiding children. Pedagogic is a theory that carefully, critically and objectively develops its concepts of human nature, the nature of children, the nature of educational objectives and the nature of the educational process.

This is in line with what Kunandas said, education is living together in the trinity of the father-mother-child trinity, where the implementation of values, with which he proceeds to finally be able to carry out himself as a human being. Through KKG, teachers have opportunities and potentially discuss problem-solving faced in the classroom, including in improving teacher competency. Trimo (2007, p.12) suggests that coaching through the KKG provides an opportunity for wider teachers (possible all teachers are involved), compared to other forms of coaching (must wait for an opportunity). Uceh Nurabnu (2012, pp. 24) The Kindergarten Task Force is a forum for the activities of Teachers Working Group (KKG) and Head of Kindergarten Working Group (KKKTK) which has been established through the Director General of Primary and Secondary Education, Ministry of Education and Culture No. 086 / c / Kep / v / May 8, 1995. KKG / MGMP Development Standards Directorate of Educator Professors Directorate General of Quality Improvement of Education and Education Personnel of the Ministry of Education and Culture of the Republic of Indonesia stated that KKG is a forum or activity for professional teachers of Primary School / Madrasah Ibtidaiyah at cluster or sub-district level consisting of several teachers from various schools. Teacher Working Group is a structural professional organization established by teachers in a region or cluster of schools as a vehicle for sharing experiences to improve teachers' ability and improve the quality of learning (Trimo, 2007, p. 12). Based on the description, the researchers see how important to improve the performance of early childhood teachers, in addition, to develop creativity and train to innovate in teachers. To that end, the researcher wanted to study how to improve the competence of Kindergarten teacher through teacher workgroup in Cimahi Central Bakung group.

\section{B. METHOD}

The approach used in this research is qualitative. The method in this research is a descriptive method, which aims to make the description, picture or painting systematically, factually and accurately about facts, properties and relationship between phenomena investigated. This research was conducted one month twice, with a population in cluster Bakung Cimahi Tengah which amounted to 29 teachers from 7 kindergarten schools. For the assessment of many studies, there were seven teachers composed of one sample school representative. The technique of collecting data is done through observation, documentation study, literature study and interview.

\section{RESULTS AND DISCUSSION}

A. Findings of Research Results

The objective condition of teachers in the cluster of lilies, according to the supervisor of TK Cimahi Tengah revealed that the performance of teachers in kindergarten especially in this cluster is still relatively below the level of achievement and not yet understand and understand, in the field such as monitoring, supervision or similar things, even the less varied or unique learning and only glued to the existing magazine, this researcher took the initiative to provide guidance and special direction to teachers in this 
cluster of lilies, especially one month of meetings held once for repeating or mining insights for the performance they deliver in the schools they teach can achieve good performance, as for the guidance and guidance that supervisors will then provide to teachers attending this teacher working group in order to improve the performance of teachers in particular in the cluster of daffodils. Here is a progress chart on teacher performance coaching.

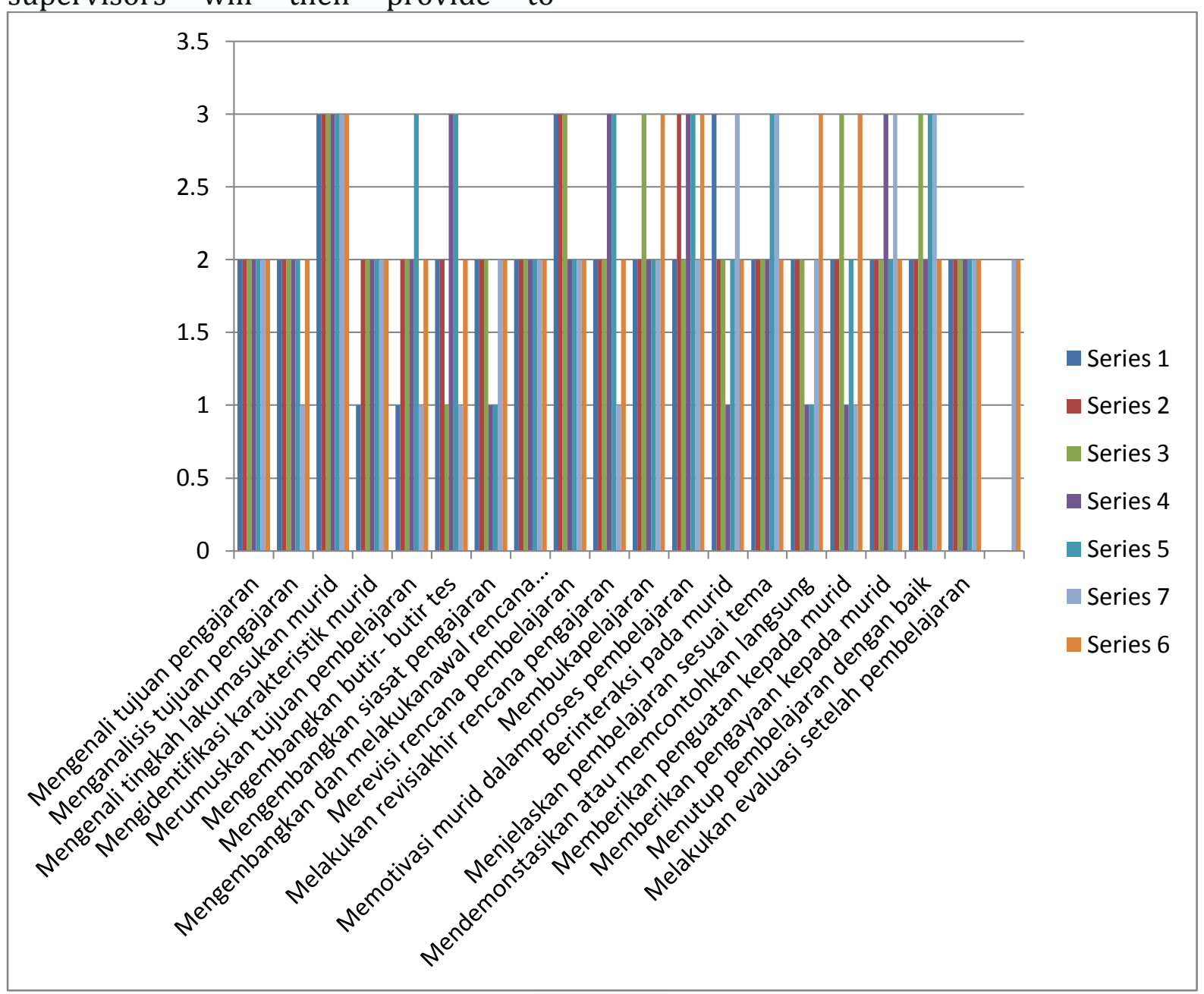

Chart 4.1

\section{Graph of Development on Teacher Performance Development}

\section{B. Discussion}

1) Research Objective Conditions

Based on the result of preliminary observation done by the researcher, the competence of kindergarten teacher in this cluster there is some aspect that the average has not seen, such as in school activity, that is to recognize the purpose of teaching, to formulate the learning objectives, develop the learning items, the content of teaching purpose, recognize student input behavior, identify student characteristics. This is in line with Ronald Brandt's renewal of the curriculum and application of new teaching methods, ultimately depending on the teacher. (Prof. Dr. Endang Komara, M.Si, p. 70).

Based on observations of the lack of such competence in teachers such as formulating learning objectives, developing learning points, teaching objectives, recognizing student input behavior, identifying student characteristics. Learning activities in 
adults should always be oriented to the needs of adults themselves and require a stimulus in the process of coaching to optimize all work activities. Meanwhile, according to Knowles (Prof. Pupuh Fathurrohman and Dr. Aa Suryana, M.M, pp. 142), andragogy is a technology of involvement is as an art and science to help the students. Thus, supervisors provide mobilization and guidance to teachers in the lily clusters that will be thorough through their classroom teachers and principals of various types of learning activities through teacher work groups should be based on the development of the times and needs of each teacher and institution.

2) Implementation of Teacher Working Group

At the time of the process of implementing the working group of teachers in the cluster of bakung progress, the teachers still look not to understand its role as a subject of learning. Nevertheless, teachers began to look enthusiastic during discussions about the activities to be carried out. Teacher working group is one of the latest methods that can improve the quality of competence and develop creativity because the working group of teachers is a more emphasize approach constructivists on teacher position as the subject of active learning. In addition, in particular, the teacher working group, in its implementation is oriented towards efforts to increase competence.

In relation to the above, in the teacher workgroup activities, to improve the competence of teachers experienced a significant increase or gradually. This is because researchers and supervisors of TK cooperate to try various activities with the different discussion but still aim to examine performance aspect according to the existing indicator. Learning activities that build strong collaboration on the work unit of the teacher workgroup.

The established and employed teacher working group provides positive values and can generate confidence in work and ultimately can provide greater awareness and tolerance. This is in line with Stenhouse (Prof. Dr. Endang Komara, M. Si, 92) argues that the research teacher actually performs as expected in the concept of extended professionalism, which develops perspective, skills, and involvement.

3) Results After Working Group Teacher Working

The data obtained from this research is to develop the kindergarten teacher competence through the teacher workgroup in the cluster of daffodil that gets the result from observation. The observation data was conducted to find out the improvement of the Kindergarten teacher competence in the cluster of dolphins through the teacher workgroup, while the active learning was conducted to determine the final ability of the teacher after being assisted through this teacher working group.

From the results of research on the subject of the researcher it can be concluded that the seven subjects of this research successfully develop the competence of teachers through the teacher workgroup because it looks after doing three times the average teacher show an active attitude in the activity, the teacher was enthusiastic and very happy to receive learning through the group teacher work, due to the development of performance by kindergarten supervisors that are well packaged and interesting so that the teacher enjoys doing coaching activities through teacher workgroup.

Thus increasing the competence of teachers through the teacher workgroup can experience a significant 
increase as when supervisors provide direction and coaching look more active and confident. Based on all observation data above, it can be concluded that improving teacher competence through a working group of the teacher more effective and better, teacher better understand and can do the activity well.

This is paralleled by Siagian (Prof. Pupuh Fathurrohman and Dr. Aa Suryana, M.M, 27) competence is an achievement of a particular work that can ultimately be directly reflected in the resulting outcome. Thus in developing the performance of teachers must go through a process of structured or gradual learning or learning. Teacher working groups are one of the supporters to improve teacher competence, recognize teaching objectives, formulate learning objectives, develop learning items, teaching objectives, recognize student input behavior, identify student characteristics.

Therefore, the competence of teachers is needed and needed by everyone, especially on the teacher, recognize the purpose of teaching, to formulate the learning objectives, develop the learning items, the content of the teaching objectives, to recognize the student's input behavior, to identify the characteristics of pupils that should always be stimulated and directed positive by people in the neighborhood.

\section{CONCLUSION}

Based on the results of the research can be obtained the following conclusions.

1. Initial conditions based on observations made by the researchers, showed that the competence of kindergarten teachers in this cluster of daffodils there are some aspects that the average has not seen, such as school activities, recognize the purpose of teaching, formulate learning objectives, develop learning points, content the purpose of teaching, recognizing the behavior of students' input, and identifying the characteristics of the pupil.

2. During the process of implementation of the working group of teachers in the cluster of daffodils, teachers begin to look enthusiastic during the discussion about the activities to be implemented. Teacher working group is one of the latest methods that can improve the quality of competence and develop creativity because the teacher working group is a more energetic constructive approach on the teacher position as an active learning subject. In addition, in particular, the teacher working group, in its implementation is oriented towards efforts to increase competence.

3 . The results of the research on the seven subjects studied showed that the competence of teachers successfully developed through the teacher working group, because it looks after three meetings the average teacher showed an active attitude in the activity, the teacher was enthusiastic and very happy to receive learning through teacher workgroup, due to the development of competencies by kindergarten supervisors that are well packaged and interesting so that teachers are happy to conduct coaching activities through teacher workgroups.

Based on the above statement that improving the competence of teachers through the teacher workgroup can experience a significant increase as when supervisors provide direction and coaching looks more active and 
confident. And based on observational data, it can be concluded that improving teacher competence through teacher workgroup is more effective and better and teacher better understand and can do an activity well.

\section{E. REFERENCES}

Abdul Majid. (2013). The Planning of Learning to developing teacher competency standards. Bandung: PT Remaja Rosdakarya.

Enueme, C. P., \& Egwunyenga, E. J. (2008). Principals' instructional leadership roles and effect on teachers' job performance: A case study of schools in Asaba Metropolis, Delta Sate: Nigeria.

Kentucky Education Professional Standards Board. (2003). Kentucky Teacher Standards for Preparation and Certification: Interdisciplinary Early Childhood Education Birth to Primary. [Online]. Tersedia: http://www.epsb.ky.gov/teacherpre p/iecestandards.asp. [7 April 2013].

Spencer. (1993). Competence Work: Model for Superior Performance. New York: John Wiley \& Sons Inc.

Suparno. (2005). Increase the quality of education. Jakarta: Depdiknas.

Wahjosumidjo. (1995). Principal Leadership. Jakarta: Raja Grafindo Persada.

Yufiarti \& Chandrawati. (2011). Teachers' competence in teaching: Jakarta: Penerbit Universitas Terbuka.

Yufiarti \& Chandrawati, T. (2009). PAUD Teacher Professionalism. Jakarta: Penerbit Universitas Terbuka. 